RESEARCH PAPER

\title{
SLURRY EROSION BEHAVIORS OF COPPER ALLOY BARREL OF MEASURE- MENT WHILE DRILLING
}

\author{
Kang Jin Huang ${ }^{1,2 *}$, Kun Xia Wei ${ }^{1,2 *}$, Ke Zhang ${ }^{3} \uparrow$, Wei Wei ${ }^{1,2} \dagger$, Qing Bo Du ${ }^{1,2}$, Igor V. Alexandrov \\ $2,4+$ \\ ${ }^{1}$ School of Materials Science and Engineering, Changzhou University, Changzhou 213164, P. R. China \\ ${ }^{2}$ Jiangsu Key Laboratory of Materials Surface Science and Technology, Sino-Russian Joint Laboratory of Functional \\ Nanostruc-tured Materials, Changzhou University, Changzhou 213164, P. R. China \\ ${ }^{3}$ School of Metallurgical Engineering, Maanshan University of Technology, Maanshan 243032, P. R. China \\ ${ }^{4}$ Department of Physics, Ufa State Aviation Technical University, 12 K. Marx St., 450008 Ufa, Russia
}

†Corresponding author. E-Mail: huzhude@ yeah.net (K. Zhang), benjamin.wwei@163.com (W. Wei); IgorVAlexan-drov@yandex.ru (Igor V. Alexandrov), Tel.:+ 7-927-930-38-44, Department of Physics, Ufa State Aviation Technical University, 12 K. Marx St., 450008 Ufa, Russia

* These authors contributed equally to this work.

Received: 30.01 .2021

Accepted: 06.02.2021

\begin{abstract}
Measurement while drilling (MWD) has been widely used in petroleum drilling engineering because it can realize borehole trajectory monitoring and improve the drilling speed. However, the slurry erosion will deteriorate and shorten the life of MWD. A user-defined function (UDF) code was developed to calculate the particle properties (particle impact velocity, particle impact angle and particle impact number) and erosion depth to understand the erosion process. The results show that the Realizable $\kappa-\varepsilon$ model can accurately predict the erosion profile and the erosion depth is consistent with the experiment results. Furthermore, high pressure will aggravate surface damage and expand the area of slurry erosion. It has been demonstrated that computational fluid dynamics (CFD) and experimental approach can be used to identify and explain the erosion mechanisms in different regions where the surface morphologies reveal four erosion patterns, namely, micro-cutting, cracks, pits and plastic deformation.
\end{abstract}

Keywords: MWD; Slurry erosion; Copper alloy; High pressure; CFD

\section{INTRODUCTION}

Measurement while drilling (MWD) is a kind of advanced drilling equipment, which has been widely applied because it can realize well trajectory monitoring and improve the drilling efficiency. In drilling operations, sand can provide the energy needed to break hard rock in a fast and cost-effective manner $[1,2]$. On the other hand, sand particles can bring about various problems, such as pressure drop, pipe blockage and erosion [3]. When solid particles in the fluid impact the copper alloy barrel of MWD, the equipment is prone to damage and failure, resulting in huge economic losses $[4,5]$. Therefore, in order to ensure the safe operation of MWD instrument and reduce the damage caused by the slurry erosion, an accurate erosion prediction is prerequisite.

The slurry erosion is a very complex phenomenon, which is affected by many factors such as particle impact velocity, particle impact angle and particle impact number and mechanical properties of barrel materials. For brittle materials [6], the erosion is mainly caused by cracking and peeling of barrel materials. For ductile materials [7-9], the erosion is generated by a series of repeated micro-plastic deformations.

In order to study the erosion rate and establish an erosion model, the Slurry Pot Erosion Test, Coriolis Test, Direct Impingement Jet Test and Pipe Loop Test [10-12] are provided to carry out standard experimental tests. DVN [13], E/CRC [14], Oka [15, 16], Grant and Tabakoff [17] erosion models are widely used owing to their relative simplicity and accuracy. However, in the fully automatic drilling environment, the determination of $3 \mathrm{D}$ erosion distribution is still challenging due to the long time and high cost of wall thickness monitoring. Computational fluid dynamics (CFD) can estimate particle microscopic characteristics that cannot be observed in the experimental methods. It is widely used for particle erosion prediction of related geometric shapes such as pipelines, tee pipes at sudden expansions and contractions [18-20]. However, no CFD investigation to date has been conducted to examine the slurry erosion behaviors of copper alloy barrel of WMD.

In the present, a combined numerical and experimental approach was used to investigate the erosion-induced surface evolution as well as the erosion mechanisms on the surface of the MWD barrel. CFD simulation results are helpful to make an insight into the particles impact on MWD barrel surface and the process of removing the material.

\section{EXPERIMENTAL PARAMETERS}

MWD testing system is mainly composed of ground equipment and downhole measuring instruments as shown in Fig. 1. Particles are irregularly shaped quartz sand with a density of 2450 
$\mathrm{kg} / \mathrm{m} 3$ and the diameter in the range of $0.1 \sim 0.3 \mathrm{~mm}$. The viscosity of the drilling fluid is $47.5 \mathrm{CP}$ and the density is 1325 $\mathrm{kg} / \mathrm{m} 3$. Detailed composition of MWD barrel and experimental conditions are shown in Table 1 and Table 2. The relation between drilling fluid velocity $\mathrm{u}$ and fluid flow $\mathrm{Q}$ is referred to Eq. (1):
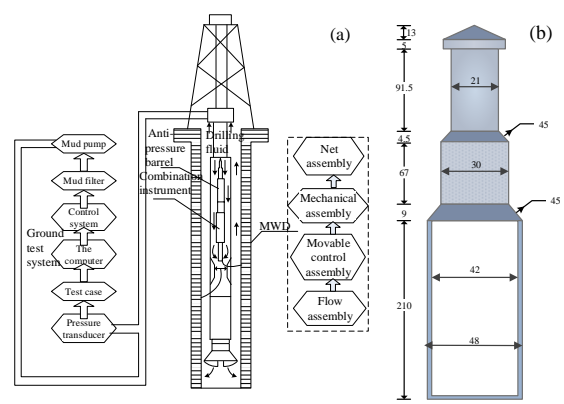

Fig. 1 Schematic of the experimental facility. (a) MWD testing system, (b) MWD barrel (mm)

$$
u=\frac{C \cdot Q}{2.448 \times D^{2}}
$$

$\mathrm{Q}(\mathrm{L} / \mathrm{s})$ is the fluid flow, $\mathrm{C}$ (3.117) is the empirical coefficient, and $\mathrm{D}(0.083 \mathrm{~m})$ is the length scale of the fluid.

The total mass loss of MWD barrel was measured by the electronic balance. The local erosion depth and surface morphology were characterized by Super Depth 3D microscope (Keyence, VHX-6000)

Table 1 Experimental conditions

\begin{tabular}{ccccc}
\hline $\begin{array}{c}\text { Condi- } \\
\text { tions }\end{array}$ & $\begin{array}{c}\text { Fluid } \\
\text { flow } \\
(\mathrm{L} / \mathrm{s})\end{array}$ & $\begin{array}{c}\text { Particle } \\
\text { concentra- } \\
\text { tion }(\%)\end{array}$ & $\begin{array}{c}\text { Working } \\
\text { pressure } \\
(\mathrm{MPa})\end{array}$ & $\begin{array}{c}\text { Testing } \\
\text { time }(\mathrm{h})\end{array}$ \\
\hline Test 1 & 55 & 0.5 & 0 & 200 \\
Test 2 & 35 & 0.5 & 20 & 200 \\
Test 3 & 15 & 0.5 & 20 & 200 \\
\hline
\end{tabular}

Table 2 Physical properties and composition of $\mathrm{Cu}-\mathrm{Be}(\mathrm{QBe} 2)$ alloy barrel of MWD

\begin{tabular}{cccccc}
\hline $\begin{array}{c}\text { Mate- } \\
\text { rial }\end{array}$ & $\begin{array}{c}\text { Density } \\
(\mathrm{kg} / \mathrm{m} 3)\end{array}$ & $\begin{array}{c}\text { Hard- } \\
\text { ness } \\
(\mathrm{HB})\end{array}$ & $\begin{array}{c}\text { Young's } \\
\text { modulus, } \\
\mathrm{E}(\mathrm{GPa})\end{array}$ & $\begin{array}{c}\text { Pois- } \\
\text { son's } \\
\text { ratio, } v\end{array}$ & $\begin{array}{c}\text { Yield } \\
\text { strength } \\
(\mathrm{MPa})\end{array}$ \\
\hline $\mathrm{QBe} 2$ & 8300 & 213 & 128 & 0.27 & 195 \\
\hline \multicolumn{2}{l}{ Composition (wt. \%) } & & & & \\
\hline $\mathrm{Be}$ & $\mathrm{Ni}$ & $\mathrm{Fe}$ & $\mathrm{Al}$ & $\mathrm{Si}$ & $\mathrm{Cu}$ \\
\hline 1.86 & 0.21 & 0.07 & 0.03 & 0.02 & $\mathrm{Bal}$ \\
\hline
\end{tabular}

\section{NUMERICAL SIMULATION}

\subsection{Discrete phase model}

The motion of particles is solved by Newton 's second law in the Lagrangian frame $[21,22]$, which can be expressed as:

$\frac{d v_{p}}{d t}=F_{D}\left(u-v_{p}\right)+g \frac{\left(\rho_{p}-\rho\right)}{\rho_{p}}+F$

$F_{D}=\frac{18 \mu C_{D} R e_{p}}{24 \rho_{p} d_{p}^{2}}, \quad R e_{p}=\frac{\rho d_{p}\left|u-v_{p}\right|}{\mu}$

where $F_{D}$ is the drag force per unit particle mass. In this study, $F$ represents the additional force and the pressure gradient per unit particle mass, $\mathrm{g}$ is the acceleration of gravity. $v_{p}, \rho_{p}, d_{p}, C_{D}$ and $R e_{p}$ are the particle velocity, density, diameter, drag coefficient and the Reynolds number, respectively.

The particle-wall interaction not only affects the velocity and angles, but also the trajectory of particles. The particle rebound model proposed by Forder et al [23] can be described as:

$e_{n}=0.988-0.78 \theta+0.19 \theta^{2}-0.024 \theta^{3}+0.027 \theta^{4}$

$e_{t}=1-0.78 \theta+0.84 \theta^{2}-0.21 \theta^{3}+0.028 \theta^{4}-0.022 \theta^{5}$

where $e_{n}$ and $e_{t}$ are the normal and tangential restitution coefficients, respectively. $\theta(\mathrm{rad})$ is the particle impact angle.

\subsection{Erosion model}

Oka erosion model $[15,16]$ is obtained on the basis of a large number of erosion experiments. The relationship between $K(\alpha \cdot H V)^{k}{ }_{l}^{b}$ and $E_{90}$ at reference impact velocity can be derived based on Oka experimental results. The function of $\mathrm{SiO}_{2} \sim \mathrm{Cu}$ is described as [16]:

$K(\alpha \cdot H V)^{k_{1} b} \approx 81.714(H V)^{-0.15}$

$E R=10^{-9} \times \rho_{w} \cdot K(\alpha H v)^{k_{1} b}\left(\frac{V}{v_{\text {ref }}}\right)^{k_{2}}\left(\frac{d_{p}}{d_{\text {ref }}}\right)^{k_{3}} g(\theta)$

$k_{2}=2.3(H V)^{0.038,} \quad H B=\frac{H V+0.1023}{0.0108}$

The $E R(\mathrm{~kg} / \mathrm{kg})$ is defined as the mass of removed material from the sample divided by the mass of erodent impacting the surface. $\rho_{w}$ and $H V(\mathrm{GPa})$ are the density and Vickers hardness of the target material, respectively. $d_{r e f}$ and $v_{\text {ref }}$ are the reference particle diameter $(326 \mu \mathrm{m})$ and the velocity $(104 \mathrm{~m} / \mathrm{s})$ of the particle, respectively. $k_{2}$ is the particle impact velocity exponent, $k_{3}$ is determined by the properties of the particle. The detailed parameters are listed in Table 3 .

The impact angle function $g(\theta)$ is defined by:

$$
\begin{aligned}
& g(\theta)=(\sin \theta)^{n_{1}}(1+H V(1-\sin \theta))^{n_{2}} \\
& n_{1}=0.71(H V)^{0.14}, \quad n_{2}=2.4(H V)^{-0.94}
\end{aligned}
$$

where $n_{l}$ and $n_{2}$ are determined by the particle properties and the eroded material hardness. The impact angle function $g(\theta)$ of $\mathrm{SiO}_{2} \sim \mathrm{QBe}_{2}$ is shown in Fig. 2.

Furthermore, in the present a user defined function (UDF) code is developed into the ANSYS FLUENT software to calculate the erosion depth and total mass loss:

$\Delta W=\mathrm{ER} \cdot m_{i} \cdot t \times 1000, \quad \Delta \mathrm{h}_{i}=\frac{E R_{i} \cdot m_{i} \cdot t}{\rho_{w} \cdot A_{i}} \times 1000$

where $\Delta h_{i}(\mathrm{~mm})$ and $\Delta w(\mathrm{~g})$ are the erosion depth and total mass loss, respectively. $t(\mathrm{~s})$ is the test time. $m_{i}(\mathrm{~kg} / \mathrm{s})$ is the mass rate of particles impacting the computational cell area $A_{i}\left(\mathrm{~m}_{2}\right)$.

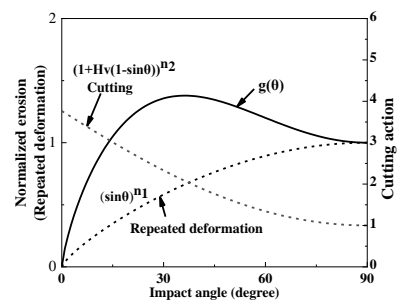

Fig. 2 The erosion arising from repeated plastic deformation and cutting action according to Eq. (9)-(10) 
Table 3 Parameters for Oka erosion model

\begin{tabular}{cccc} 
Material type & $\begin{array}{c}\mathrm{QBe}_{2} \\
(\mathrm{C} 17200)\end{array}$ & $\begin{array}{c}\text { Model constant, } \\
\mathrm{n}_{2} \\
\text { Velocity expo- } \\
\text { nent }\end{array}$ & 1.14 \\
$\begin{array}{c}\text { Particle type } \\
\text { Reference } \\
\text { erosion rate } \\
\text { Wall material } \\
\text { Vickers } \\
(\mathrm{GPa})\end{array}$ & 0.0006026 & $\begin{array}{c}\text { Diameter expo- } \\
\text { nent }\end{array}$ & 0.19 \\
$\begin{array}{c}\text { Model con- } \\
\text { stant, } \mathrm{n}_{1}\end{array}$ & 2.2 & $\begin{array}{c}\text { Reference diame- } \\
\text { ter }(\mathrm{m})\end{array}$ & 0.000326 \\
& 0.79 & $\begin{array}{c}\text { Reference veloc- } \\
\text { ity }(\mathrm{m} / \mathrm{s})\end{array}$ & 104 \\
\hline & & &
\end{tabular}

\subsection{Computational mesh and geometry}

Fig. 3 shows the simplified geometry and the mesh used in the CFD simulation. Three kind of meshes as shown in Fig.4 were created by ICEM to conduct the mesh refinement study, with a refinement ratio of 1.5 .

The grid convergence method proposed by Roache [24] is used to analyze the uncertainty of the upstream average erosion rate caused by the grid refinement in Table 4 . To obtain representative average velocity and turbulence fluctuations value of particle interaction in the near-wall cell, it is recommended to set the thickness of the first layer equal to the particle size [25-27]. The convergence index for coarse and intermediate meshes is $4.8 \%$ while intermediate and finer meshes is $0.84 \%$. Meanwhile, the asymptotic range of convergence is 0.97 and the order of grid convergence is 4.39. As it can be seen, the intermediate mesh is sufficient to meet the simulation accuracy requirements.

Table 4 Parameters setting of grid refinement study (Realizable $\kappa-\varepsilon$ model)

\begin{tabular}{cccc}
\hline $\begin{array}{c}\text { Mesh } \\
\text { group }\end{array}$ & $\begin{array}{c}\text { Refine- } \\
\text { ment ratio }\end{array}$ & $\begin{array}{c}\text { The number } \\
\text { of elements }\end{array}$ & $\begin{array}{c}\text { Average ero- } \\
\text { sion rate } \\
\left(\mathrm{kg} / \mathrm{m}^{2} \cdot \mathrm{s}\right)\end{array}$ \\
\hline $\begin{array}{c}\text { Mesh } \\
1\end{array}$ & 1 & 68640 & $5.96 \times 10^{-6}$ \\
$\begin{array}{c}\text { Mesh } \\
2\end{array}$ & 1.5 & 220320 & $5.01 \times 10^{-6}$ \\
$\begin{array}{c}\text { Mesh } \\
3\end{array}$ & 2.25 & 717810 & $4.85 \times 10^{-6}$ \\
\hline
\end{tabular}

3.3. Boundary conditions and numerical schemes

ANSYS FLUENT 2019 was used for numerical simulations. For complex flow problems involving pressure gradient and impact, non-equilibrium wall functions are recommended [28]. The boundary conditions adopt velocity inlet and pressure outlet. The turbulence specification method was used taking into account the turbulence intensity $(5 \%)$ and hydraulic diameter $(0.083 \mathrm{~m})$. The Couple-Pseudo transient algorithm was used to solve the pressure-velocity coupling problem and QUICK discretization scheme was used to determine the momentum, the convection and divergence terms, and the PRESTO for the pressure term.

As the particle concentration is low, one-way coupling can be employed. The Rosin-Rammler model [29] is used to calculate the particle distribution. The average particle diameter is estimated as $0.000181 \mathrm{~m}$, the particle distribution exponent is 2.5 and the non-spherical coefficient is 0.8 .

\section{RESULTS AND DISCUSSION}

4.1. Turbulence model analysis

Different types of turbulence models will lead to different turbulence scales, which will lead to differences in particle trajectory prediction. In this study, three turbulence models of Realizable $\kappa-\varepsilon$, SST $\kappa-\omega$ and RSM are used to analyze the erosion rate of MWD barrel [30]. The experimental data from Test 1 was used to determine which model performed best in predicting the overall erosion profile.

As can be seen from Table 5, the total mass loss of RSM model and SST $\kappa-\omega$ model is close to the experiment values, while the Realizable $\kappa-\varepsilon$ model is obviously over-predictive in the downstream of MWD. The significant erosion localization is found by the SST $\kappa-\omega$ model and RSM model in Fig. 5(b) and (c), but the experimental erosion profile is dispersed and randomly distributed. In comparison with the experimental data, the erosion depth and erosion profile predicted by the SST $\kappa-\omega$ model and RSM model are not as good as that by Realizable $\kappa-\varepsilon$ model in Fig. 5(a) and Fig. 6. Therefore, the Realizable $\kappa-\varepsilon$ model is selected as turbulence model for the CFD simulation.

Table 5 Comparison of total mass loss with different turbulence models

\begin{tabular}{ccccc}
\hline $\begin{array}{c}\text { Condi- } \\
\text { tions }\end{array}$ & $\begin{array}{c}\text { Realiza- } \\
\text { ble } \kappa-\varepsilon \\
(\mathrm{g})\end{array}$ & $\begin{array}{c}\text { SST } \kappa-\omega \\
(\mathrm{g})\end{array}$ & RSM $(\mathrm{g})$ & $\begin{array}{c}\text { Experi- } \\
\text { ment }(\mathrm{g})\end{array}$ \\
\hline Test1 & 81.35 & 45.36 & 47.53 & 57.23 \\
Test2 & 21.18 & 11.08 & 11.25 & 23.28 \\
Test3 & 7.6 & 4.19 & 4.32 & 14.52 \\
\hline
\end{tabular}

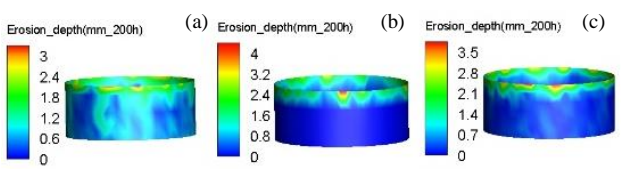

Fig. 5 Contours of erosion depth with different turbulence models (Test1): (a) Realizable $\kappa-\varepsilon$, (b) SST $\kappa-\omega$, and (c) RSM

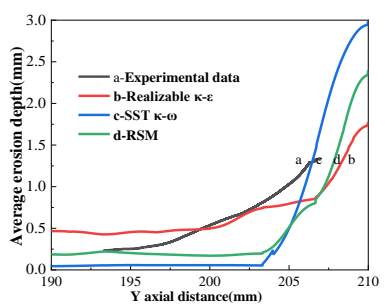

Fig. 6 Comparison of average erosion depth with different turbulence models (Test1)

\subsection{Comparison between CFD simulation and experimental results}

A combination of CFD calculation and experimental results is conducted to study the influence of fluid flow on the slurry erosion process and erosion mechanism. Under different fluid flows, the erosion distribution of MWD barrel by the simulation and experimental results is shown in Fig. 7. The erosion wear is mainly distributed in the upstream of MWD barrel.

Since the MWD barrel is not a plane, there is a curvature error in the radial direction. In the experiment measurements, it is noted that the erosion profile is distributed randomly. In order to reduce the measurement error, the multiple line data in the Yaxis direction are extracted and averaged. For Test 1 , the erosion wear is mainly distributed in the range of $200-210 \mathrm{~mm}$. Generally the trend of erosion wear decreased gradually from the top to the bottom in the upstream of MWD barrel. CFD simulation can well predict the erosion profile, and the predicted erosion depth is relatively consistent with the experimental data as shown in Fig. 7(a) and Fig. 6. Under high pressure and high fluid flow (Test 2), the interaction between particle erosion and pressure, the area of slurry erosion is expanded and the erosion depth is increased in Fig. 7(b) and Fig. 8. In the range of 205-210 mm, CFD can better predict the erosion depth, which is agreement 
with the experimental measurement. When Von Mises stress becomes larger in the range of 190-200 mm, plastic deformation caused by high pressure dominates, and it is difficult for the existing erosion model to predict complex conditions as shown in Fig. $8[31,32]$. For Test 3 , the erosion wear are negligible in comparison with the experimental measurement. Surface damage may be caused by plastic deformation due to high pressure, resulting in a uniform concave in the middle and convex on both sides in the upstream of MWD barrel in Fig. 7(c). (a)

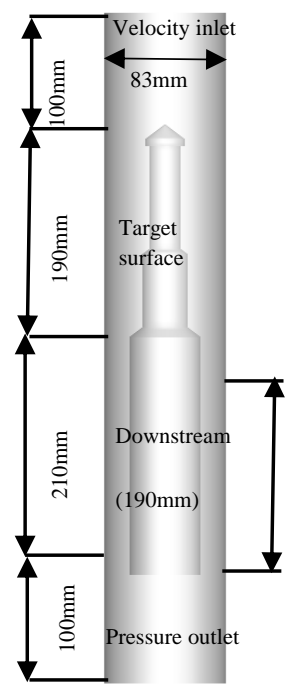

(b)

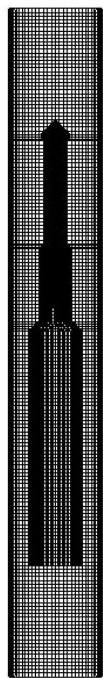

(c)

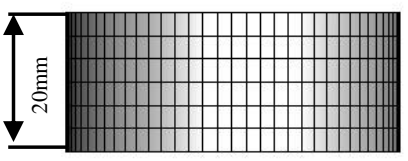

Fig. 3 Geometry and mesh of MWD barrel. (a) geometry, (b) computational domain, (c) upstream

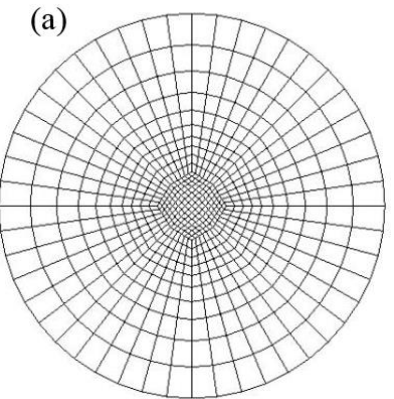

(b)

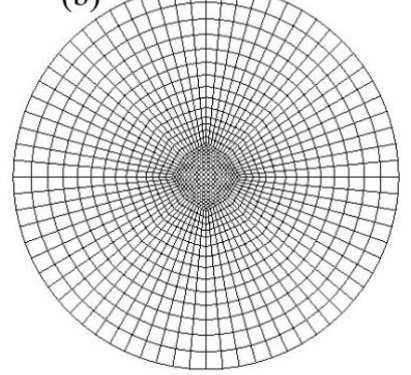

(c)

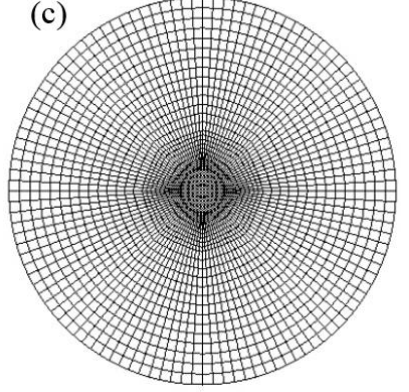

Fig. 4 Different density of mesh on the cross-section. (a) Coarse mesh, (b) Intermediate mesh, (a) Fine mesh

(a) Erosion_depth(mm_200h) 3
2.7
2.4
2.1
1.8
1.5
1.2
0.9
0.6
0.3
0
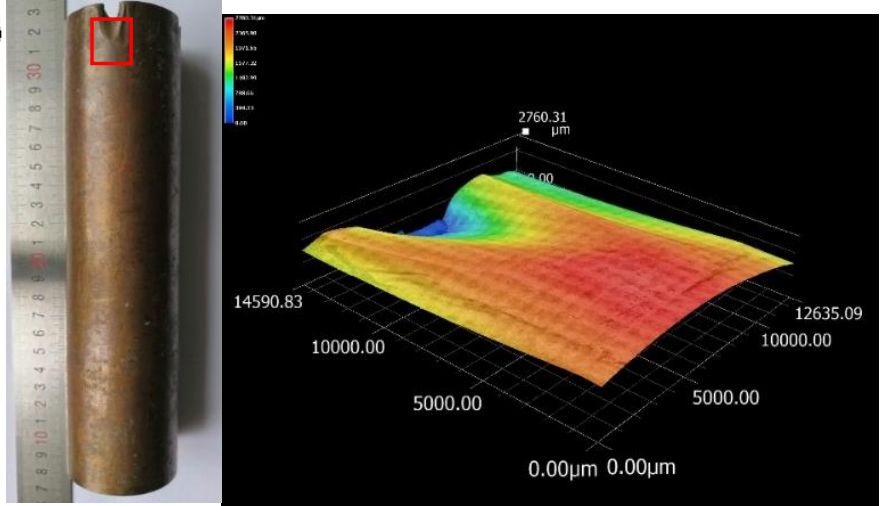
(b) Erosion_depth(mm_200h)
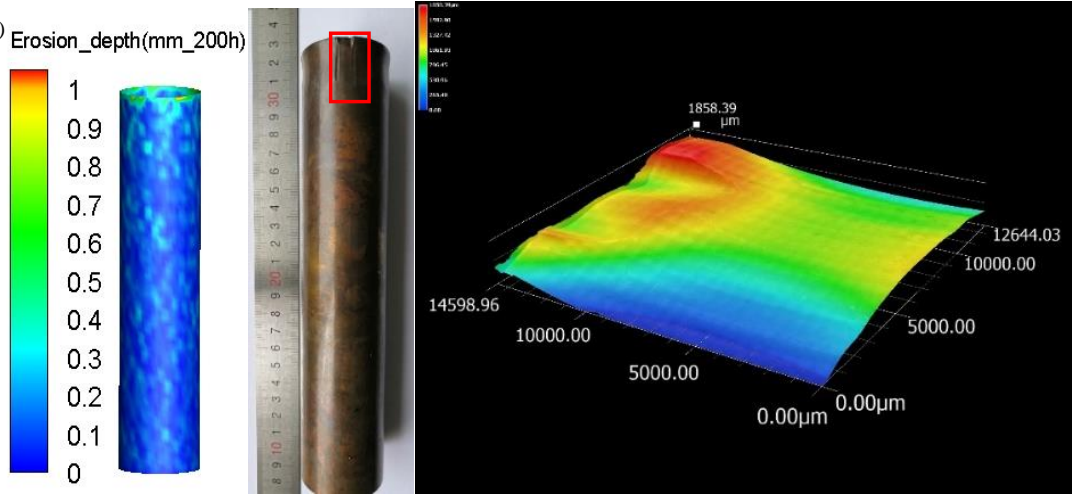

${ }^{(c)}$ Erosion_depth(mm_200h)
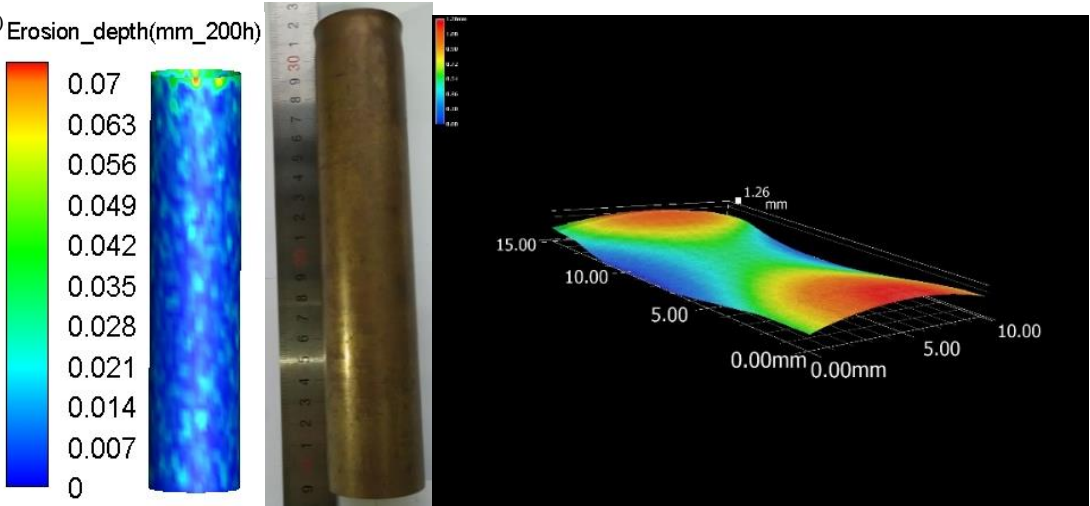

Fig. 7 Comparison between the actual erosion wear and the CFD predictions. (a) Test 1, (b) Test 2, (c) Test 3

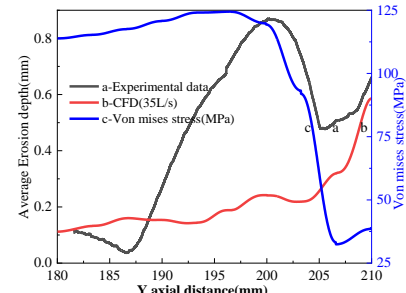

Fig. 8 Comparison of the average erosion depth and Von Mises stress with actual erosion (Test 2)

To further understand the erosion process and erosion mechanism, the surface morphology of MWD barrel after erosion is observed by Super Depth 3D microscope. The erosion morphology is mainly affected by the particle impact velocity, particle impact angle and Von Mises stress. Figure 9 shows the contours of erosion-related variables (such as erosion depth, particle impact velocity, particle impact angle and sand mass per unit area) under different fluid flow. It can be seen that the fluid flow has a certain degree of influence on the shape of the erosion scar. As the particle velocity decreases, the ability of fluid flow to carry particles becomes stronger, and more particles will impact the surface of MWD barrel in the upstream with the fluid, and the impact angle will increase. Therefore, the combination of CFD simulation and experimental approach can be used to identify and explain the slurry erosion mechanism in different regions.

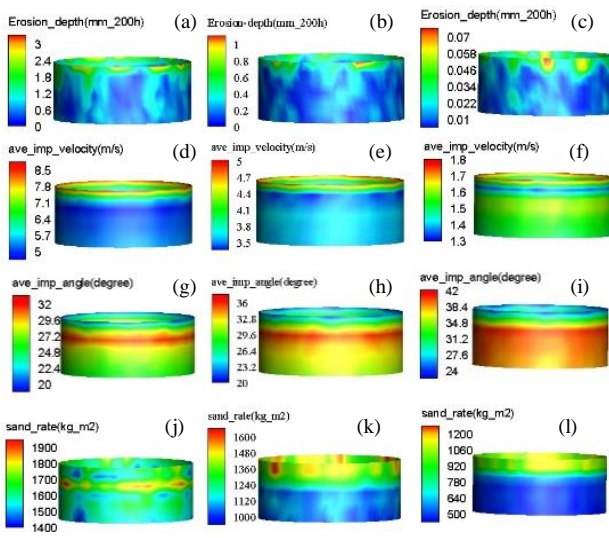

Fig. 9 Contours of erosion-related variables (including erosion depth, particle impact velocity, particle impact angle and sand mass per unit area) with different fluid flow: Test 1 (a, d, g and j), Test 2 (b, e, h and k), Test 3 (c, f, i and l)

Under high fluid flow (Test 1), small fragments were induced by the repeated cutting actions of high-velocity particles at low impact angle. These fragments were washed away by the incoming slurry and subsequently removed from the material surface, resulting in scratches and vulnerable lip formation [33,34] as 
shown in Fig. 10(a) and (b). Under high pressure and high fluid flow (Test 2), the impact force of the particles becomes bigger, the pits form on the surface and are becoming larger and deeper in Fig. 10(c) and (d). In the middle of the upstream (195-200 $\mathrm{mm}$ ), the Von Mises stress and particle impact angle become bigger, plastic deformation and cracks caused by indentation dominate in Fig. 10 (e) and (f) [34-36]. Under high pressure and low fluid flow (Test 3 ), the particle impact velocity is relatively low, but the impact angle increases. The micro-pits and scratches form, resulting in a large number of micro-pits and scratches in Fig. 10(g) and (h). These slurry erosion characteristics are very similar to the experimental study of slurry erosion results [34].

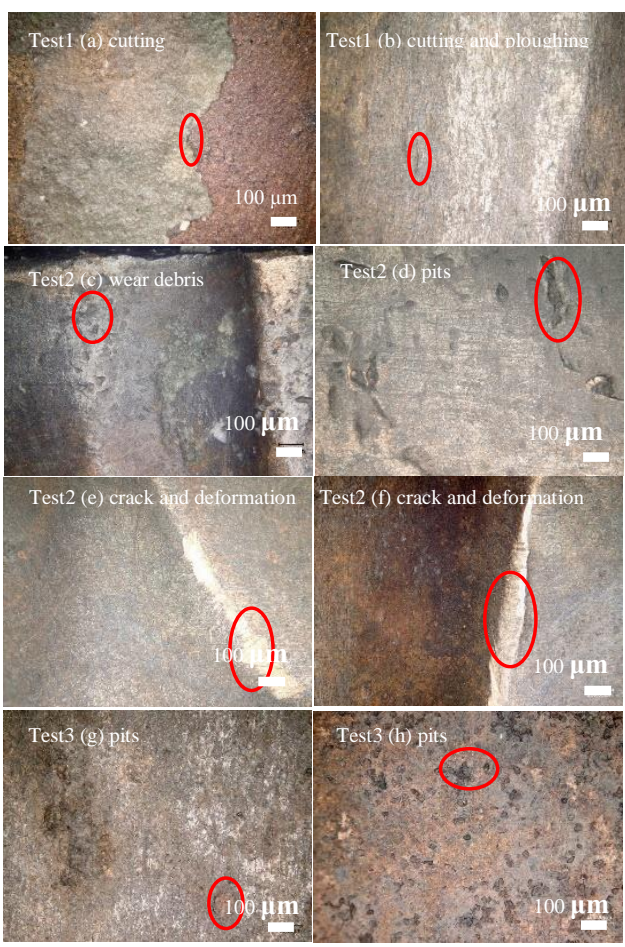

Fig. 10 Surface morphologies in different regions of MWD barrel. (I) in the top of upstream (205-210mm): (a), (c), (d) and (g), (II) in the middle of upstream (195-200mm): (b), (e), (f) and (h)

\section{CONCLUSIONS}

1) The SST $\kappa-\omega$ and the RSM model predictions are insufficient in particle-fluid interaction, showing the obvious erosion localization in the upstream of MWD barrel. The realizable $\kappa-\varepsilon$ model can well predict the erosion profile and the erosion depth is consistent with the experiment results.

2) Under high fluid flow, particle erosion wear is mainly distributed in the range of $200 \sim 210 \mathrm{~mm}$, and the overall trend gradually decreases from the top to the bottom of MWD barrel; under high pressure and high fluid flow, particle erosion and pressure interaction further expand the area and the depth of slurry erosion; under high pressure and low fluid flow, the particle erosion is negligible, and plastic deformation caused by high pressure is dominant.
3) A user defined function (UDF) code is developed to calculate the particle characteristics to understand the slurry erosion process and explain the erosion mechanisms. The impact of particles at high velocity and low angle is dominated by the cutting mechanism. Under high angle and high Von Mises stress, plastic deformation caused by indentation is dominated; for high velocity of particles, large pits and cracks are formed, and micro-pits and scratches form at low velocity particles.

\section{ACKNOWLEDGMENTS}

The authors are grateful to be supported by the Priority Academic Program Development of Jiangsu Higher Education Institutions (PAPD), the Top-notch Academic Programs Project of Jiangsu Higher Education Institutions (TAPP), and the Science and Technology Project of Changzhou, P. R. China under grant No.CZ20180016 and CE20170028.

\section{REFERENCES}

1. J. Zhao, G. Zhang, Y. Xu: Powder Technol., 313, 2017, 231-244.

http://doi.org/10.1016/j.powtec.2017.03.026.

2. F. Wang, R. Wang, W. Zhou: Int. J. Impact Eng., 102, 2017, 169-179.

https://doi.org/10.1016/i.ijimpeng.2016.12.019.

3. M. Parsi, K. Najmi, F. Najafifard, S. Hassani, B.S. McLaury, S.A. Shirazi: J. Nat. Gas. Sci. Eng., 21, 2014, 850873.

http://doi.org/10.1016/j.jngse.2014.10.001.

4. G.C. Pereira, F.J. de Souza, D.A. de Moro Martins: Powder Technol., 261, 2014, 105-17.

http://doi.org/10.1016/i.powtec.2014.04.033.

5. A. Mansouri, H. Arabnejad, S.A. Shirazi, B.S. McLaury: Wear, 332-333, 2015, 1090-1097. http://doi.org/10.1016/j.wear.2014.11.025.

6. I.M. Hutchings: Wear, 70, 1981, 269-281. https://doi.org/10.1016/0043-1648(81)90347-1.

7. M.A. Islam, Z.N. Farhat: Wear, 311, 2014, 180-190. http://doi.org/10.1016/i.wear.2014.01.005.

8. Q.B. Nguyen, C.Y.H. Lim, V.B. Nguyen, Y.M. Wan, B. Nai, Y.W. Zhang, M. Gupta: Tribol. Int., 79, 2014, 1-7. http://doi.org/10.1016/j.triboint.2014.05.014.

9. I. Finnie: Wear, 186-187, 1995, 1-10. http://doi.org/10.1016/i.triboint.2014.05.014.

10. M. Lindgren, J. Perolainen: Wear, 321, 2014, 64-69. http://doi.org/10.1016/j.wear.2014.10.005.

11. H.S. Grewal, H. Singh, E.-S. Yoon: Wear, 332-333, 2015, 1111-1119.

http://doi.org/10.1016/j.wear.2015.02.039.

12. C.Y. Wong, C. Solnordal, L. Graham, G. Short, J. Wu: wear, 336-337, 2015, 72-85.

http://doi.org/10.1016/j.wear.2015.04.020.

13. D.N. Veritas: Recommended practice RP O501 erosive wear in piping systems, 2007. http://shaghool.ir/files/erosivewear-in-piping-systems-rp-o501.pdf.

14. Y. Zhang, E.P. Reuterfors, B.S. McLaury, S.A. Shirazi, E.F. Rybicki: Wear, 263, 2007, 330-338.

http://doi.org/10.1016/i.wear.2006.12.048.

15. Y.I. Oka, K. Okamura, T. Yoshida: Wear, 259, 2005, 95101. 
http://doi.org/10.1016/j.wear.2005.01.039.

16. Y.I. Oka, T. Yoshida: Wear, 259, 2005, 102-109.

http://doi.org/10.1016/j.wear.2005.01.040.

17. G. Grant, W. Tabakoff: J. Aircraft., 12, 1975, 471-478.

https://doi.org/10.2514/3.59826.

18. R.E. Vieira, A. Mansouri, B.S. McLaury, S.A. Shirazi: Powder Technol., 288, 2016, 339-353.

http://doi.org/10.1016/j.powtec.2015.11.028.

19. W. Peng, X. Cao: Powder Technol., 294, 2016, 266-279. http://doi.org/10.1016/j.powtec.2016.02.030.

20. M. Agrawal, S. Khanna, A. Kopliku, T. Lockett: Wear, 426-427, 2019, 596-604.

https://doi.org/10.1016/j.wear.2019.01.018.

21. A. Mansouri: A combined CFD-experimental method for developing an erosion equation for both gas-sand and liquidsand flows, The University of Tulsa, 2016.

22. A. Haider, O. Levenspiel: Powder Technol., 58, 1989, $63-$ 70.

https://doi.org/10.1016/0032-5910(89)80008-7.

23. A. Forder, M. Thew, D. Harrison: Wear 216, 1998, 184 193.

https://doi.org/10.1016/S0043-1648(97)00217-2.

24. P. J. Roache, K. N. Ghia, F. M. White: J. Fluids Eng., 108 1986, 2.

http://doi.org/10.1115/1.3242537.

25. F. Najafifard: Predicting near wall particle behavior with application to erosion simulation, The University of Tulsa, 2014.

26. T. A. Sedrez, S. A. Shirazi, Y. R. Rajkumar: Wear 426 2019, 570-580.

https://doi.org/10.1016/j.wear.2019.01.015.

27. A. Mansouri, H. Arabnejad, S. Karimi, S.A. Shirazi, B.S. McLaury: Wear, 338-339, 2015, 339-350.

http://dx.doi.org/10.1016/j.wear.2015.07.011.

28. J. Zhang, F. Darihaki, S.A. Shirazi: Wear, 430-431, 2019, 191-201.

https://doi.org/10.1016/j.wear.2019.04.029.

29. P. Rosin: J. Fluids Eng., 7, 1933, 29-36.

30. J. Zhang, B.S. McLaury, S.A. Shirazi: Wear, 394-395, 2018, 11-19.

http://doi.org/10.1016/j.wear.2017.10.001.

31. H. Wang, Y. Yu, J. Yu, Z. Wang, H. Li: Tribol. Int., 137, 2019, 387-404.

https://doi.org/10.1016/j.triboint.2019.05.019.

32. H. Wang, Y. Yu, J. Yu, W. Xu, X. Li, S. Yu: Wear, 440441, 2019, 203043.

https://doi.org/10.1016/j.wear.2019.203043.

33. T. Alam, Z.N. Farhat: Eng. Fail. Anal., 90, 2018, 116-128. https://doi.org/10.1016/j.engfailanal.2018.03.019.

34. B. Sun, J. C. Fan, D. Wen: Tribol. Int., 82, 2015, 280-286. http://dx.doi.org/10.1016/.triboint.2014.07.025.

35. R. Bidulsky,M. Actis Grande, E. Dudrova, M. Kabatova, J. Bidulska: Powder Metall., 59(2), 2016,121-127

https://doi.org/10.1179/1743290115Y.0000000022.

36. J.Bidulská, R. Bidulský, M.A. Grande, T. Kvačkaj: Materials, 12(22), 2019, 3724.

https://doi.org/10.3390/ma12223724. 